\title{
NOTE
}

\section{RECENT STATUTORY REGULATION OF CONSUMER SALES FINANCING AS EXEMPLIFIED BY AUTOMOBILE SALES ACTS}

If $A$, having no ready cash, wishes to buy an automobile, at least two ways are available to finance the sale. (1) He may borrow from a third person and pay the seller in cash. (2) He may buy on the installment plan at a price higher than the cash price, the difference being the finance charge for the seller's extension of credit. In essence the two transactions are the same; they permit $A$ to obtain present goods in return for his obligation to pay in the future. At common law the usury laws would prevent an exorbitant charge in the first situation, but not in the second. The reason given by the courts for this distinction was that a sale of goods is not a loan and there can be no usury in the absence of 'a loan. ${ }^{1}$ This distinction enabled the installment seller, by virtue of his superior bargaining position, to charge interest rates, termed "finance charges,". that were grossly in excess of a return commensurate with the costs and risks of extending credit to the buyer. The purpose of this Note is to explore the many abuses which the installment selling of consumer goods, especially automobiles, has engendered, and to evaluate the statutory remedies passed to curb them.

The exorbitant finance charge is probably the most significant problem raised by installment selling, as it confronts the buyer as soon as the installment payments begin. In addition, other abuses are prevalent in this field. Sellers often do not disclose the full terms of the contract to the buyer but instead have him sign a "blank" contract in which harsh terms are subsequently inserted, to the buyer's surprise. When the buyer defaults the goods are often repossessed without prior notice and his right to the goods is cut off forthwith regardless of his equity in them. ${ }^{2}$

1. This reasoning has been followed in a long line of decisions stemming from the early English case of Beete v. Bidgood, [1828] 7 B. \& C. 453, 108 Eng. Rep. 792 (1827). See e.g., Hogg v. Ruffner, 1 Black 115 (U.S. 1861); Thomas v. Knickerbocher Operating Co., 108 N.Y.S.2d 234 (Sup. Ct. 1951) ; Morris Plan Industrial Bank of Schenectady v. Faulds, 269 App. Div. 238, 55 N.Y.S.2d 372 (3d Dep't 1945). For a discussion of this subject, see Berger, Usury in Instalment Sales, 2 Law \& Contemp. Pror. 148, 172 (1935).

2. See a general discussion of all the above-cited evils and abuses in Nugent and Henderson, Installment Selling and the Consumer: A Brief for Regulation, 173 Annals 93 (1934). Certainly the Uniform Conditional Sales Act (hereinafter cited U.C.S.A., provides inadequate protection from the abuses of installment selling. It was written several years before their prevalence and before the advent of the finance company in automobile financing. At the time of the Act's passage, conditional sales contracts were used mainly in commercial sales between manufacturers and purchasers of goods in large quantities. The act does deal with reposses- 
The entrance of the finance company into the field as the assignee of the installment contract creates many new problems. The buyer is sometimes prevented from asserting contract defenses, such as breach of warranty, against the finance company's collection of payments on the assigned contract. A more widespread abuse is the finance company's insistence upon the execution of a note by the buyer, which, because it is generally held to be negotiable, cuts off as to the endorsee finance company the butyer's contract defenses against the original seller. ${ }^{3}$

The importance of installment selling in the principal retail establishments is shown by the following table:

The percentage of Installment Sales to Total Sales in each field, 1929-1946.

Automobiles Furniture Household Appliances Jewelry

$\begin{array}{llll}60 & 40 & 50 & 21\end{array}$

The dominant position of automobile installment sales is indicated as follows : ${ }^{4}$

Percentage Distribution of all Installment Credit by Six Types of Retail Establishments, 1929-1946.

\section{Department}

Automobiles Stores
12.5
Household

Appliances
Al1

$\begin{array}{ccc}\text { Jewelry } & \text { Others } & \text { Total } \\ 2.3 & 8.6 & 100\end{array}$

The vast growth of the automobile industry brought about a novel method of marketing to distribute automobiles to the consumer. Mass production had brought with it an enormous expansion of installment credit without which the mass buying of automobiles would not have been possible. However, the dealer-seller was unable to grant credit on such a large scale. To fill this need the finance company emerged in American economic life to take the key position in granting consumer credit.

sion, redemption and resale. However, as will be discussed below, some of these provisions seem unsuited for modern 'retail installment selling.

An example of such a provision is that which permits the seller to cut off the buyer's right of redemption merely by serving advance notice of intention to repossess the goods $(\$ 18)$. The inadequacy of the Act as applied to the modern consumer sale is pointed out in Donaldson, Retail Installment Sales Legislation, 19 RockY MT. L. REv. 135, 158 (1947).

3. See Gilmore, On the Difficulties of Codifying Commercial Law, 57 Yale L.J. 1341, 1350 (1948). See also Notes, 44 ILL. L. REv. 227, 230 (1949), 57 YaLE L.J. 1414 (1948) which discuss the attempts to make installment sales contracts themselves negotiable as well as cases in which buyer has executed a separate promissory note.

4. The figures for these two tables were compiled from data in Cox, THE. Economics of INSTALMent Buying 24-33 (1948) and Retail Installarent Selling, Research Report 16, Research Div. Maryland Legislative Council 10-13 (1940). From 1929 to 1949 the volume of installment sales credit exceeded the total of all other forms of consumer credit such as installment loans and singlepayment loans. See Cox, sipra, at 485-489. 
The problems created by installment selling are complicated by the many different types of security interests which sellers use. Historically, different legal consequences follow, depending upon whether the security device used by the seller in the installment sales contract is a conditional sale, a bailment lease or a chattel mortgage. ${ }^{5}$ These three common forms of installment contract differ as to the procedure which the seller follows in exerting his rights in the event of default. ${ }^{6}$ They often differ in the rights and defenses remaining in the buyer in the event of default. For example, in Pennsylvania, an installment buyer formerly had very little protection against harsh repossession practices because the seller commonly employed the "bailment lease", which is exempt from the coverage of the Pennsylvania version of the Conditional Sales Act. ${ }^{7}$ Although courts are naturally antagonistic to harsh contract provisions and might be led to find some grounds on which to hold for the buyer, nevertheless buyers have often acquiesced because they had neither the money nor inclination to go to court.

There is no reason why the relative rights of both the seller and buyer in the retail transaction should not be the same regardless of which form of security device is used. This thought is reflected in the Uniform Commercial Code ${ }^{8}$ and in the states which have passed special legislation to protect the installment buyer in the retail sale situation. These acts are couched in broad enough terms to include all types of security devices

5. Some form of security device or title retention is universally used by the installment seller. It permits the seller to threaten to repossess or actually repossess goods in the event of nonpayment. A bailment lease is an arrangement by which goods are hired for a specified period, the bailee ordinarily having an option to buy the goods for a nominal sum after all the installments have been paid. A conditional sale is a sale conditioned upon the buyer's payment of the purchase price; the buyer has possession of the goods and seller can repossess only in the event of buyer's default. In a chattel mortgage arrangement the buryer obtains present title as well as possession. The buyer then transfers back to the seller a limited security interest in the goods, which seller may exercise, by foreclosure, in the event of default by the buyer.

6. In the few states where the bailment lease is used, notably Pennsylvania, the seller has an effective method of self help. He is bound to no formal methods of repossession. This was also true when the conditional sale was employed prior to the U.C.S.A. However, the conditional seller was commonly subjected to the rule of election. He had to choose between suing for the price or disaffirming the transaction through repossession. In the chattel mortgage situation foreclosure is often a cumbersome process for seller. But the doctrine of election does not generally apply against the mortgagee. See HaNNA, CASES AND MATERIAIS on SEcurity 254-255 (2d ed. 1952) : 1 WiLliston Sales $\$ \$ 336-338$ (2d ed. 1924) ; 2 id. $\$ \$ 579-$ $579(\mathrm{a})$.

7. Compare $\S 1$ of the U.C.S.A. with PA. STAT. ANn. tit. 69, $\$ 361$ (Purdon 1931). In addition to being subject to lessor's right of seif-help, the lessee is not permitted to raise lessor's breach of warranty as a defense to an action for repossession by lessor. The cases imply that the lessee will be held to the terms of the contract and have no period of redemption following repossession. See Lee-Strauss Co. v. Kelly, $292 \mathrm{~Pa}$. 403, 141 Atl. 236 (1928); Judson C. Burns, Inc. v. Weinberg, $119 \mathrm{~Pa}$. Super. 571, 181 Atl. 460 (1935); Valicenti v. Central Motors, Inc. $115 \mathrm{~Pa}$. Super. 74, 174 At1. 799 (1934).

8. Uniform Commercial Cone Art. 9 (Official Draft 1952) (hereinafter cited U.C.C.). For a discussion of the Secured Transactions article of the Code see Schwartz, Pennsylvania Chattel Security and the Uniform Connercial Code, $98 \mathrm{U}$. of PA. L. Rev. 530 (1950) ; Gilmore, The Secured Transactions Article of the Commerical Code, 16 Law \& Contemp. Prob. 27 (1951). 
employed by the seller. 9 Some of these statutes apply whether or not the seller retains any form of security interest in the goods sold..$^{10}$

In recent years thirteen states, recognizing the need for counterbalancing the installment buyer's inferior bargaining power, have passed legislation aimed at placing him in a more advantageous position. These statutes vary considerably in their approach as well as in their coverage. ${ }^{11}$ Five of them apply only to the sale of automobiles, ${ }^{12}$ while the remainder apply to all goods. The remedial provisions of these statutes will be examined and compared with the Uniform Conditional Sales Act ${ }^{13}$ and the new Uniform Commercial Code.

\section{The Contract Document}

Requiring the terms to be in zeriting.-A major criticism of installment selling generally, and especially of automobile installment selling, has been that the buyer often was ignorant of his rights and liabilities under the contract. Either no written contract was ever executed by the parties or the seller had the buyer sign a blank contract in which the seller

9. See e.g., the Pennsylvania statute, PA. STAT. ANN. tit. 69, $\$ \$ 600-637$ (Purdon 1951) which defines an installment sales contract as, ". . . any contract for the retail sale of a motor vehicle, ... under which part or all of the price is payable in two or more scheduled payments subsequent to the making of such contract, . . . and shall include any loan, any mortgage, any conditional sale contract, any purchasemoney chattel mortgage, any hire-purchase agreement ..." Section 603 (10).

10. Ohto Gen. Code Ann. §6346-15 (Page Supp. 1952); Pa. Stat. Ann. tit. 69, $\$ 603$ (Purdon Supp. 1951).

11. Two states have disclosure laws which prescribe what information must be included within the written contract. CAL. CIV. CODE $\$ \$ 2981-82$ (1949); N.Y. PERS. PRop. LAw $\$ \S 64-a, 80-b, 81$. The Utah statute merely subjects the installment sale to the Usury laws. UTAF CODE ANN. tit. 44, \$44-0-2 (1943). The remaining states have more comprehensive statutes regulating every phase of the installment sales transaction. Conn. Rev. Gen. Stat. \$\$ 5963-68, 6698-6704 (1949); IND. ANn. Stat. $\$ \S 58-901-34$ (Burns 1951); Me. Rev. Stat. c. 56, $\$ 264$ (1944); Md. Ann. Code GEN. Laws art. 83, $\$ 116-52$ (Cum. Supp. 1947) ; Mass. AnN. Laws c. 255, §\$11-13 H (Cum. Supp. 1951) ; MICH. Stat. ANN. \$19.415 (Cum. Supp. 1951); N.J. Stat. Ann. $\$ \$ 17: 16$ B (1950); Ohio Gen. Cone Ann. \$\$ 6346-15-27, 9589-5 (Page Supp. 1952); PA. Stat. AnN. tit. 69, $\$ \$ 600-637$ (Purdon Supp. 1951); Wis. Stat. \$218.01 (1947). See also HawaII Rev. Laws \$\$9141-69 (1945); Hire-Purchase Act, 1938, 1 \& 2 GEo. 6, c. 53. Hereinafter specific provisions in these state statutes are referred to by state name and section number.

12. California, Maine, Michigan, Pennsylvania and Wisconsin. The Massachusetts and Ohio statutes apply to all installment sales. The other statutes that apply to all goods limit this coverage to sales below a maximum price. These limitations do not impede the effectiveness of the statutes, which are aimed at protecting the consumer rather than the commercial buyer. See N.Y. PERS. Prop. LAw $\$ 64-a$, which regulates the contents of installment sales contracts, and exempts goods sold for commercial use.

13. The U.C.S.A., withdrawn from active promulgation by the Commissioners in 1943, has been adopted, with variations in some states, in the following jurisdictions: Alaska Comp. Laws ANN. tit. 29, c. 2, $\$ \$ 1-28$ (1949); ARIz. Code ANN. c. 52, $\$ 601-620$ (1939); DEL. REv. CODE c. 173, $\$ 5951-5979$ (1935) ; HaWAII REv. LAwS $\$ \$ 9141-9169$ (1945) ; IND. ANN. STAT. $\$ \$ 58-801$ to 58-829 (Burns 1951); N.H. Laws c. $104, \S \S 1-32$ (1945); N.J. STAt. ANN. tit. 46, c. 32, $\$ \$ 1-33$ (1940); N.Y. PERs. Prop. LAW, $\$ \$ 60-81$; PA. Stat. ANN. tit. 69, $\$ \$ 361-504$ (Purdon 1931) ; S.D. Code $\$ \$ 54.0201-54.0229$ (1939); WIS. Stat. c. 122, $\$$ 01-31 (1947); W. VA. Code ANn. $\$ \$ 4007-4038$ (1949). 
subsequently placed oppressive contract terms. The buyer had no idea what the various charges were that made up the total price of the goods or how they were calculated. He often did not understand under what conditions the goods would be repossessed until the repossessor confronted him:14 This policy of nondisclosure precluded the buyer from being able properly to compare purchasing on time with other means of obtaining the goods, such as borrowing money from a bank or saving until he could make a cash purchase. ${ }^{15}$ To eliminate these evils, eleven of the thirteen states ${ }^{10}$ now require the entire contract to be in writing setting forth the unpaid balance of the cash price, the various finance and insurance charges, the buyer's liability respecting default and repossession and his right to redeem the goods. Several states further provide that the contract must contain a prominently printed caveat to buyers not to sign the contract in blank and a statement that the buyer is entitled to an exact copy of the document. ${ }^{17}$ These disclosure provisions are often accompanied by sanctions invalidating the contract, in whole or part, for the seller's failure to comply with the statute. ${ }^{18}$ In the main these sanctions have been strictly enforced against the seller or contract holder. ${ }^{19}$

Finance Charges.-The most talked-about abuse connected with installment selling is the seller's exorbitant finance charge. Despite this

14. For general discussion of the above mentioned abuses brought about by the buyer's unawareness of contract terms, see, Nugent and Henderson, Installment Selling and the Consumer: A Brief for Regulation, 173 ANNALs 93 (1934); Donaldson, Retail Installment Sales Legislation, 19 RockY MT. L. REv. 135, 142 (1947); Note, Protecting the Installment Buyer, 49 HARv. L. Rev. 128 (1935).

15. Undoubtedly one of the most important influences curbing the volume of installment selling and, therefore, the number of abuses in it during the past few years has been Regulation W of the Federal Reserve Board. It was first promulgated as a defense measure, under a presidential order, and was intended to help prevent inflation and discourage purchases of consumer goods during the war. Exec. Order No. 8843, Aug. 9,1941, 3 Code Fed. Regs. c. 2 (Cum. Supp. 1943). It controlled over-extension of credit by prescribing a one-third down payment on all installment sales of automobiles and a fifteen percent down payment on all installment sales of household effects. The time balance on all of these sales was limited to eighteen months. 32 A. CODE FED. REGS. c. 15 (Rev. ed. 1951). To the extent that these regulations prevented financially irresponsible buyers from purchasing on time, they eliminated many buyers who would have been subjected to the abuses at which modern sales legislation is directed. Regulation $W$ was withdrawn from operation in May, 1952.

16. Maine and Utah are the exceptions.

17. E.g., MaRYLaND, $\S 117$ (c).

18. MassachusetTs, $\S \S 12,13$ A (vendee shall have valid defense against recovery of finance charge by vendor in the event of non-compliance with written contract provision, and no contract shall be valid unless it apprises buyer of his rights upon default); MARYLAND, $\$ 136$ (seller shall not collect any finance or delinquency charge); MICHIGAN $\$ 19.415$ (2) (seller shall not collect any finance charge).

19. See, e.g., Lehan v. North Main St. Garage, Inc., 312 Mass. 547, 45 N.E.2d 945 (1942) holding that seller, who did not comply with statute invalidating sales contract unless it apprises buyer of his rights upon default, lost his security title and therefore could not recover for conversion of automobile against buyer's transferee. In Stride v. Martin, $184 \mathrm{Md}$. 446, 41 A.2d 489 (1945) a copy of the contract delivered to buyer was not signed by seller as the statute required [MARYLAND, $\$ 116$ (c)]. The Court held that the buyer was entitled to recover all payments made, after seller had "repossessed." 
fact only six states have directly dealt with the problem by establishing maximum rates which the seller may charge. ${ }^{20}$ These states have recognized that the policy behind usury laws and their offshoot, the small loans acts, applies in the installment selling field. ${ }^{21}$. Maximum rates are higher than ordinary loan rates, in recognition of the increased risk involved in investigations, making collections, obtaining insurance, and depreciation of the chattel. ${ }^{22}$ Most of these states, in providing only one maximum charge, do not take into account the difference in credit risk between new or relatively new articles and old ones due to the higher rate of depreciation on older goods. The Pennsylvania act, applying only to automobiles, is novel in that it sets up three different allowable maximum charges according to the age of the automobile sold. ${ }^{23}$

Writers have claimed that the exorbitant finance charge is caused in part by the competition among finance companies to obtain the retail sellers' business. ${ }^{24}$ To gain more dealer business, many finance companies have adopted the practice of rebating part of the finance charge to the retailer. The successful competitors are the ones that give the seller the largest rebate or "pack." Economists have advocated, and one state has adopted, provisions forbidding the dealer from receiving more than a stated maximum rebate when he assigns an installment contract. ${ }^{25}$ The theories behind condemning or restricting rebates are: (1) the buyer does

20. California, \$2982(c); Indiana, \$906; Ohio, §6346-20; Pennsylvania, $\S 619$; UTAK, $\$ 44-0-2$. In Wisconsin the Banking Commission requires finance companies to file maximum rate charts. If the Commission thinks that these rates are reasonable it has the power to prevent companies from exceeding them. Donaldson, Retail Installment Sales Legislation, 19 Rocky MT. L. Rev. 135, 146 (1947).

21. "Both transactions result in a contract for the future delivery of money." Berger, Usury in Instalment Sales, 2 LAw \& ConTeMr. PROB. 148, 153 (1935).

22. See Ecker, Commentary on "Usury in Instalment Sales," 2 Law \& ConteMr. Prop. 173, 176 (1935). Utah fixes maximum interest rates for both loans and credit sales under the same statutory provision. UTAF CoDE ANN. tit. 44, \$44-0-2 (1943).

Methods of computation of rates, based upon seller's risks, and their relative merits are discussed in Mors, State Regulation of Retail Installment FinancingProgress and Problems, 24 Journal of Bustness of the Untversity of Chicago 48 (Jan. 1, 1951).

23. The maximum rates are as follows: New automobiles, six percent per year; Used automobiles not more than two years old, nine percent per year; Used automobiles over two years old, twelve percent per year. Pennsylvania, \$619. In Indiana the Department of Financial Institutions is empowered to fix maximum rates and has set up classes for automobile sales similar to Pennsylvania. Donaldson, supra note 20 , at 145 . Mors, supra note 22 , says of the Pennsylvania method of having three categories of charges, at 50: "(1) they permit application of the step rate idea in allowing for wide variations in loan size. (2) they permit the state to isolate the field which accounts for the bulk of the money volume of retail installment financing and in which legislative committees have found the greatest relative concentration of abuses. (3) they recognize the peculiar importance of the second hand market for cars in determining the lending risks and hence in influencing maximum rate considerations."

24. See, e.g., Nugent and Henderson, supra note 2, at 98; Cavers, The Consumer's Stake in the Finance Company Code Controversy, 2 LAw \& Contemp. ProB. 200 (1935).

25. See Nugent and Henderson, supra note 2, at 98 . The Ohio statute fixes the dealer's rebate at two percent of the principal balance of the contract, $\$ 6346-22$. The Indiana statute provides that the department may fix maximum dealer rebates, §58-910. 
not realize that the dealer is taking an undisclosed profit; and (2) since the dealer acquires immediate cash by assigning the contract, he does not deserve the rebate. However, regulating the dealer rebate is complicated by the several types of dealer-finance company contracts which are prevalent. Each type would require its own maximum limit, because they vary according to the services performed by the dealer and the extent of recourse the finance company has against the dealer in the event of default by the buyer. ${ }^{26}$ Pennsylvania and Maryland, with very extensive installment sales legislation, do not prohibit the dealer from receiving a rebate from the finance company, and their policy of non-interference seems preferable. The only justification advanced for such regulation is that it helps to protect the buyer. However, if the maximum finance charge is fixed, and legislation prescribes that such charge shall be clearly disclosed on the face of the contract, it seems that the buyer is adequately protected against the exorbitant charge. ${ }^{27}$ It is submitted that the buyer is afforded no further protection by control of the manner in which dealer and his assignee divide the finance charge. As a practical matter it is very difficult to prevent the finance company from presenting a dealer with an occasional "gift."

Assuming that full disclosure and fixing the maximum charge adequately protects the uninformed buyer by preventing exorbitant charges, a more important question appears: Do the statutes provide a clear method for stating the finance charge in the contract? All but two of the states having installment sales legislation ${ }^{28}$ require the total finance charge to be stated separately in the contract. This enables the buyer to ascertain immediately the additional cost of buying on time. The finance charge in the installment sales statutes is generally calculated as a fixed yearly percentage of the original unpaid balance of the sale. ${ }^{29}$ Since the unpaid balance declines as installment payments are made, but the interest rate remains constant, the original percentage upon which the charge is calculated is about one-half the actual yearly interest rate. For purposes of helping the buyer to compare installment purchasing with other methods of financing, it would be more desirable to require that the contract state the interest rate per year, as the well known usury laws do. This would drive home to the buyer the fact that installment purchasing is substantially more expensive than financing through a direct loan of money. ${ }^{30}$

26. For a discussion of the division of duties in the various types of dealerfinance company contracts, see Adelson, The Mechanics of the Instalment Credit Sale, 2 Law \& Contemp. ProB. 218, 220-222 (1935).

27. The Maryland statute does not fix the maximum finance charge. The policy judgment seems to be that merely requiring full disclosure will sufficiently protect the buyer, since the normal law of supply and demand will operate once the buyer knows what he is getting into.

28. The exceptions are Maine and Utah.

29. E.g., OHio, §6346-20; Pennsylvania, §619 B.

30. The statutes proceed on the theory that all allowable charges must be separately stated in the contract. But in trying to inform the buyer fully, they require the seller to list certain initial charges in the contract which, when inserted 
The states that require a written installment contract usually require that it shall contain all the agreements of the parties. ${ }^{31}$ This means the seller must set forth the rate of additional charges to the buyer in event of his default. Surveys show that exorbitant default and repossession charges, of which the buyer was not aware until the default occurred, have constituted a major abuse in installment selling. ${ }^{32}$ Several states go further than merely providing that the conditions of default must appear in the contract, and set maximum limits on these charges. ${ }^{33}$

Insurance.-Univertsally, the seller requires accident insurance to protect the security interest which he and his assignee have in the automobile. $^{34}$ Before the enactment of the modern legislation, the buyer often did not get full information on either the coverage or the cost of the insurance policy. Sellers would lump the insurance cost together with finance and other charges and this concealment facilitated the seller's taking a very handsome commission on the writing of the buyer's insurance. Sellers were often prompted more by considerations of which insurance company gave seller the largest commission or condoned his raising the premium rate than by considerations of the financial stability of an insurance company and the broadest coverage for the buyer. ${ }^{35}$ Today most of the states requiring a written contract require that the cost of insurance to the buyer and a brief summary of its coverage be separately stated in the contract. $^{36}$ They also require a copy of the insurance policy to be furnished the buyer shortly after the installment contract is signed. Pennsylvania and Michigan provide that the buyer may choose his own insurers. This provision would seem to help eliminate the practice of the seller's charging insurance rates higher than those generally charged by insurance companies for comparable coverage. However, since neither state requires that the installment contract set forth the buyer's right to procure his own insurance, he may never know of this right.

in addition to the more significant charges, unduly lengthen and complicate it. These include filing fees, notarization fees, and, if a motor vehicle, registration and driver's license fees. Preventing the seller from charging more than the actual costs of these fees and expenses can be accomplished just as effectively by raising the maximum finance charge to the extent of such costs and forbidding the separate statement of these charges. By this means the contract may be simplified without depriving the buyer of any statutory protection.

31. See, e.g., Michraan, $\$ 19.415(2)$. This prevents the seller from taking advantage of the lack-of-integration exception to the parol evidence rule.

32. See Nugent and Henderson, supra note 2, at 96; RETAIL INSTALLMENT Semiling, Research Report 16, sipra note 4, at 29.

33. Connecticut, §6699; Indiana, § 58-926(c); Maryland, § 132; New Jersex, $\$ 17: 16 \mathrm{~B}-6$, OHIo, $\$ 6346-20$; Pennsylvania, \$621. Several of these statutes permit these charges to be imposed only after a default of a certain number of days.

34. As between the parties the risk of loss is usually placed upon the buyer. See U.C.S.A. \&27. Under a bailment lease where property is destroyed through no fault of the bailee, he is not liable in the absence of a contract provision enlarging his liability so that he is an insurer. McCoy v. Home Ins. Co., $170 \mathrm{~Pa}$. Super. 38, 84 A.2d 249 (1951).

35. Seller is only interested in obtaining coverage for the goods, whereas the buyer might desire personal liability insurance.

36. E.g., Pennsylvanta, \$614B(4). 
Although most states regulate maximum insurance rates and license insurance agents, these regulations do not answer the question of whether or not the retail seller is allowed to charge for handling the procurement of insurance for the buyer. Maryland is the only state which directly answers this question negatively. ${ }^{37}$ Many states permit the seller to list incidental charges in the contract representing expenses by the seller in carrying out the contract. ${ }^{38}$ It is conceivable that sellers make extra insurance charges through such expense clauses.

\section{Prohibited Contract Provistons}

Installment sales legislation has prohibited a number of contract clauses which are unnecessary to protect the seller's interests while being unduly oppressive to the buyer. Pennsylvania and Maryland forbid insecurity clauses under which any part or all of the unmatured time balance may be declared immediately due because the seller or assignee deems himself insecure. ${ }^{39}$ The harshness of such clauses has been minimized by courts that have required reasonable ground for fear rather than mere apprehension before enforcing them against the buyer. ${ }^{40}$ In cases of actual default by the buyer, every state but Maryland ${ }^{41}$ allows a seller or holder to impose a contract clause declaring the entire balance due.

Buyers frequently have had to acquiesce in contract provisions authorizing forcible entry, with an accompanying waiver of damages, in repossession of the goods or in the collection of payments. Such provisions are forbidden by the Pennsylvania and Maryland statutes. ${ }^{42}$ These states also prevent a seller or his assignee from relieving himself of liability for acts of his agents through a contract provision whereby the buyer executes a power of attorney appointing the seller as the buyer's agent in collection of payments or in repossession of goods. ${ }^{43}$ Moreover, they outlaw the "balloon" contract which precipitates default and repossession by providing for small periodical payments, terminating in one very large payment. ${ }^{44}$

Several states prohibit a clause giving the seller or assignee a power of attorney to appear for the buyer and confess judgment upon default, in view of buyer's inequality of bargaining power. ${ }^{45}$ The importance of

37. Maryland, $\$ 119(\mathrm{a})$. Cf. Pennsylvania, $\$ 617(\mathrm{c})$ which provides that the insurance charge shall not be in excess of the cost others pay for similar.coverage.

38. See note 30 supra.

39. Maryland, \$118(d); Pennsylvania, §615B.

40. E.g., Hines v. Pacific Car Co., 110 Wash. 75, 188 Pac. 29 (1920). 3 Jones, Chattel Mortgages and Conditional Sales \$1296 (6th ed. 1933).

41. Maryland, $\$ 129(1)$.

42. Maryland, §118(e); Pennsylvania, $\$ 615 \mathrm{C}, \mathrm{D}$. The statutes do not specify the sanction for violating this prohibition.

43. Maryland, §118(f); Pennsylvania, § $615 \mathrm{E}$.

44. Maryland, \$118(c); Pennsylvania, \$615 F.

45. E.g. Maryland, \&118(b); New Jersey, \$17:163-6(a) (3). Cf. Wisconsin, $\$ 270: 69$, which permits warrants of attorney to confess judgment only on a bond or promissory note. This statute has been construed to prohibit entering a judgment on a warrant of attorney contained in a conditional sale contract. Chippewa Valley Securities Co. v. Herbst, 227 Wis. 422,278 N.W. 872 (1938). 
such protection is lessened, because courts generally closely scrutinize such clauses and readily open judgments in order that buyer may defend. ${ }^{46}$

\section{Buyer's Defenses Against Finance Company}

Pennsylvania and Maryland are the only states that deal with the special problems created by the assignee finance company's intervention. The Pennsylvania Motor Vehicles Sales Finance Act forbids contract provisions relieving the assignee from liability for any legal remedies which the buyer may have against the seller under the contract. ${ }^{47}$ American case law generally has given the buyer protection against these waiver or cut-off clauses in sales contracts by declaring them void as against public policy. ${ }^{48}$ Nevertheless a number of court decisions have upheld such waivers against the installment buyer. ${ }^{49}$

A more serious impairment of the buyer's rights occurs when the seller requires the buyer to execute a note evidencing the contract price. In contradistinction to the general invalidity of waivers of contract breaches in assignments, the courts have generally held that such notes are negotiable, with the result that when the endorsee finance company sues upon the note, the buyer may not set off claims for breach of contract. ${ }^{50}$ Only Pennsylvania and Maryland prohibit the execution of separately negotiated notes intended to cut off as to the holder in due course any claim or defense which the buyer has against the original seller..$^{51}$

These provisions of the Pennsylvania and Maryland acts are similar to protection given the buyer of consumer goods under the Uniform Commercial Code, which declares that a holder in due course of a negotiated instrument is subject to the buyer's claims or defenses if the holder seeks to enforce the security interest, and that a clause waiving a claim or defense upon assignment of the contract is unenforceable. ${ }^{52}$

46. Ferris Motors Corp. v. Lebegern, 276 Pa. 395, 120 Atl. 394 (1923); 6 Wiruiston, Contracts $\$ 1724$ (Rev, ed. 1938).

47. Pennsyluania, $\$ 615 \mathrm{~F}$.

48. E.g., Equipment Acceptance Corp. v. Arwood Can Mfg. Co., 117 F.2d 442 (6th Cir. 1941); San Francisco Securities Corp. v. Phoenix Motor Corp., 25 Ariz. 531, 220 Pac. 229 (1923) ; Motor Contract Co. v. Van Der Volgen 162 Wash. 449, 298 Pac. 705 (1931); See First Acceptance Corp. v. Kennedy, 95 F. Supp. 861, 878 (N.D. Iowa 1951). Further cases are cited in 3 Jones, ChatTes MortgaGes aND Conditional Sales $\$ 1257$ (6th ed. 1933). See Note, Negotiability of Conditional Sales Contracts: The Consumer and Article III of the Commercial Code, 57 Y ALE L.J. 1414 (1948).

49. See cases cited in Note, 57 Y YIE L.J. 1414 n.7, 8 (1948). For a discussion of negotiability, citing extensive authority both upholding such clauses and declaring them invalid, see Comment, 16 WASH. L. REv. 158 (1941).

50. See Note, 57 Yale L.J. 1414, 1415 n.9; See NIL \$\$ 52, 57.

51. Maryland, §134; Pennssylvanta, $\$ 615$ G. These provisions represent a major departure from negotiable instruments law. See the sections of the NIL cited in note 50 supra.

52. U.C.C. $\$ 9-206$ (1). This protection is given only to buyers of consumer goods. There is a loophole in the first of these provisions in that the holder may obtain a judgment on the note and avoid any defense under the sales contract by proceeding against the buyer, but he may not levy on the goods covered by the contract. 
It has been said that the disadvantageous positions into which the buyer may contract himself are more apparent than real. ${ }^{53}$ Since in most cases a finance company cannot afford to jeopardize its dealer's reputation in the community by refusing to allow adjustments for breach of warranty by the dealer, it would be reluctant to use its full contract rights. Therefore, recourse arrangements between the dealer and finance company, or an arrangement by which the finance company can withhold payment to the dealer under a reserve clause, are more commonly used than the waiver clause or negotiable note from the buyer. ${ }^{54}$

\section{Consequences of Default by Buyer}

In the many states where neither the Uniform Conditional Sales Act nor modern installment sales legislation is in effect, the buyer has virtually no rights in the goods after default. By using the bailment lease or conditional sale rather than the chattel mortgage the seller can cut off any right to redeem the goods after they are repossessed.55 The seller can repossess immediately upon default without giving prior notice to the buyer. The Uniform Conditional Sales Act regulates the procedure respecting repossession, redemption and resale. However, because this act was enacted before the major problems of the consumer buyer had appeared, it has been somewhat ineffectual in curbing abuses. ${ }^{56}$

Repossession.-The Uniform Act allows the seller to repossess the goods immediately upon default. ${ }^{57}$ Of the modern statutes only one requires the seller to give the buyer prior notice before taking possession of the goods, and that one is limited to household goods.58 Pennsylvania indirectly encourages prior notice and leniency by providing that the buyer may redeem the goods without paying the costs of retaking and repairing the vehicle if the seller has not waited at least fifteen days after default before repossessing. ${ }^{58}$

Redemption.-The Uniform Act is particularly inadequate with regard to redemption rights. It permits the seller to cut off the buyer's right to redeem merely by giving prior notice of his intention to repossess. ${ }^{60}$. This is considered appropriate for large commercial sales where the seller and buyer live in different cities. However, most consumer-buyers, unlike businessmen, do not realize the seriousness of default until reposses-

53. Note, 57 Yale L.J. 1414, 1417-18 (1948).

54. See note 26 supra.

55. See Cox, The Economics of Installment Buying 318-19 (1948) ; Donaldson, Retail Installment Sales Legislation, 19 Rocky Mr. L. Rev. 135, 155 (1947). For comment on the exorbitant charges for delinquency which are sometimes imposed, see Nugent and Henderson, supra note 2, at 96-98.

56. See the discussion in the U.C.S.A. in note 2 supra.

57. U.C.S.A. $\$ 16$.

58. MassachusetTs, $\$ 13 \mathrm{c}$.

59. Pennsylvania, \$ 625B2.

60. U.C.S.A. $\$ 16$. 
sion actually occurs. Moreover, problems of distance between buyer and seller which make redemption unworkable in most commercial sales are absent in the usual consumer sale, where the buyer and seller reside in the same community. Four states, recognizing these differences, give the buyer a stated period of redemption, usually fifteen days, not subject to any limitation by the seller. ${ }^{61}$ Nevertheless, in every state but Maryland, the seller may provide in the sales contract for acceleration of all future payments upon default. Hence, redemption usually means the buyer must pay all the sums remaining unpaid under the contract and not merely the amount due at the time of default. The Uniform Commercial Code is novel in that it establishes no specific redemption period. Instead, it provides that the buyer may reclaim the goods at any time before resale. ${ }^{62}$ The requirement of reasonable notice of time and place of resale apprises buyer of his redemption period. In cases where the Code authorizes the seller to retain the goods in satisfaction of the debt, he must notify buyer of such proposal. The buyer then has thirty days in which to redeem the goods by paying all sums due under the contract. ${ }^{63}$ The lack of a fixed redemption period in the Code would probably give the buyer a longer redemption period than he now has.

Resale.-Under the Conditional Sales Act, the seller must resell at public auction within thirty days after repossession when fifty percent or more of the purchase price has been paid before the goods were retaken, and must account to the buyer for any excess over price and cost. ${ }^{64}$ This forced sale provision may be detrimental to buyers because the proceeds of such sales are rarely sufficient to cover the unpaid balance, so that a large deficiency judgment often results. ${ }^{65}$ It has been suggested that it would be better to give the buyer an option of compelling resale if fifty percent or more of the price has been paid, so that he may choose between letting the goods go and reselling with the possible consequence of a deficiency judgment. .8 $^{60}$ However, this rule would work to the seller's detriment to a certain extent, for when a sale is forced upon him he frequently does not have enough time to shop around for a good price, and the requirement of a public sale diminishes any proceeds by the amount of the costs. ${ }^{67}$ These arguments for the seller become less convincing as the buyer's equity

61. MaRyLAND, \$129; MasSachusetTs, $\$ 11$; Michigan, $\$ 19.415(4)$; PenNsYLVANIA, §625. Connecticut, Indiana and New York follow the U.C.S.A. and allow the seller to cut off buyer's redemption right by giving prior notice of repossession.

62. U.C.C. \$9-506.

63. U.C.C. $\$ 9: 505(2)$.

64. U.C.S.A. \$19. CoNNECTICUT, \$6700(d); MiCHigaN, \$19.415(5).

65. See Legis., 63 Harv. L. REv. 874, 880 (1950).

66. Ibid. This option is left with the buyer in MarYLAND, $\$ 130$, and MassaCHUSETrS, $\$ 13 \mathrm{~F}$. Unless there is a resale as provided by statute the seller cannot obtain a deficiency judgment against the buyer.

67. Sellers are unenthusiastic about deficiency judgments because most of the buyer's leviable goods consist of second-hand household effects and, even in states where wages may be garnished, payments are received in dribbles. 
in the goods becomes more substantial. ${ }^{68}$ The best solution would seem to be: (1) to give the buyer the option of compelling a public resale, taking the risk of a deficiency judgment, when he has paid over a certain percentage, such as sixty percent of the purchase price; (2) to give the seller the option of compelling a public resale and taking a deficiency judgment, if necessary, when less than such percentage of the purchase price has been paid. $^{69}$ It is true that only a small number of repossessions occur after the buyer has paid a substantial amount of the original balance, ${ }^{70}$ because the holder usually continues the contract. Thus the function of the suggested buyer's option would be to protect buyers against the small minority of contract holders who would repossess and refuse to reinstate in such cases. ${ }^{71}$

\section{LICENSING AND ENFORCEMENT}

Modern installment sales statutes employ three types of sanctions to enforce their provisions: licensing of finance companies and sellers, criminal penalties for wilful violation of the acts, and civil remedies for the buyer. Seven states have a licensing system under which the administrator can revoke or refuse to issue licenses. ${ }^{72}$ Considering the general ignorance of buyers and the vast ameliorating task which these statutes undertake, licensing and a supervisory agency are indispensable to their effectiveness. ${ }^{73}$ Every state that has a licensing system also imposes a criminal penalty upon any person or group that engages in installment selling activities without having obtained a license. In addition penalties

68. Section 9-505 of the Uniform Commercial Code regards sixty percent as being a substantial equity "in" the goods.

69. These options should be required to be clearly stated in the contract for the information of the buyer. The buyer should be deemed to have exercised his option to compel a public sale unless he has delivered to the contract holder a signed statement waiving the option. Cf. U.C.C. $\$ 9-505(1)$.

70. The vast majority of defaults occur within the first three months after purchase before fifty percent of the purchase price has been paid. See Adelson, The Mechanics of the Instalment Credit Sale, 2 LAw \& ConTEMr. Pros. 218, 233 (1935). Hence, instances are rare in which a profit is made by the seller on a nonstatutory private resale, and he cannot make a profit on a statutory resale. U.C.S.A. $\S 21$.

71. This protection is needed in states where a buyer with a substantial equity in the goods is still powerless to force a public resale. E.g., PENNsylvania, \$626 $B$ gives seller complete discretion as to whether or not to have a public or private sale in any case, and authorizes a deficiency judgment after either type of sale.

72. Some states license only automobile enterprises: MAINE, §264 (finance companies) ; PENNSYLVANIA, $\$ 604$ (finance companies, installment sellers, and collectorrepossessors); WISconsIn, $\$ 218.01$ (2) (finance companies, dealers, salesmen, manufacturers, and distributors). The following states license all finance companies: ConNeCTicuT, \$5964(1); INDIANA, \$ 58-911; MARYLAND, § 141; NEW JERSEY, $\S 17: 16 \mathrm{~B} 2(\mathrm{a})$.

73. In Pennsylvania several field agents are constantly at work investigating the activities of licensees. Between October 1, 1950 and October 1, 1951, five hundred and forty-six overcharges were discovered by the examiners in approximately forty thousand contracts examined. There were over 307,000 contracts in existence during this period. Information on the number of overcharges uncovered may be secured from the Department of Banking of the Commonwealth of Pennsylvania. 
are commonly imposed for a wilful violation of any provision of the act including the furnishing of false or incorrect information requested by the administrator. ${ }^{74}$

The several statutes vary as to the types of civil recovery afforded. In Pennsylvania the buyer is given no recovery against the seller or holder who violates a provision of the act. However, if the seller or finance company is unlicensed the buyer may cancel the contract and take the vehicle free of all liens by paying the cash price. ${ }^{75}$ The Ohio, California and Maryland statutes permit the buyer to recover the entire amount he has paid on the contract for certain types of statutory violations by the seller. ${ }^{78}$ While these statutes are not clear as to the disposition of the car, it would undoubtedly have to be returned, since the remedy granted is of a restitutionary nature. ${ }^{77}$ Three states prescribe that the seller merely forfeits the entire finance charge for certain statutory violations. $^{78}$ This provision allows the buyer to retain the goods and at the same time avail himself of the penalty.

\section{Conclusion}

Most of the states that have enacted special legislation to cope with the abuses in installment selling regulate all consumer goods. ${ }^{79}$ These statutes provide the same rules and regulations for goods such as furniture as they do for automobiles. The types of abuses in the sale of household goods are mainly the same as those in the automobile field. Hence, in considering the desirability of extending the scope of the statutes now limited to aytomobile sales, and in determining the desirable scope of statutes to be enacted in the future, one major factor is the prevalence of automobile-sales abuses in other consumer goods areas.

Retailers of cheaper household commodities are more likely to finance their own. sales than are automobile dealers. Thus, the furniture buyer will only infrequently deal with an assignee finance company, whose contract immunity from buyer's defenses against seller have caused trouble in the automobile field. The household-goods seller is less inclined to repossess on default, because the resale value of used furniture and the like

74. E.g., Maryland, $\$ 150 ;$ Pennsyldanta, $\$ 637$ B.

75. Pennsyivania, $\S 635$ A.

76. The Maryland statute permits the buyer to recover all payments made on the contract if the seller fails to deliver a signed copy of the contract to the buyer within fifteen days ( $\$ 116(\mathrm{~b}))$. In Stride v. Martin, 184 Md. 446, 41 A.2d 489 (1945), the buyer recovered all payments he had made because the seller failed to sign the buyer's copy of the contract. OHIO, $\$ 6346-22$, provides that if the seller overcharges the buyer the latter may recover the entire amount paid on the contract. CALIFORNIA, $\$ \$ 2982$ (e) and (f) provide for recovery by the buyer of the amount paid under the contract for certain violations of the statute.

77. See Estrada v. Alvarez, 38 Cal.2d 386, 240 P.2d 278 (1952) (plaintiff sued on a rescission theory under CaLrForNIA, $\$ \$ 2982(e)$ and (f)).

78. Connecticut, §6703; New Jersey, §17:16 B 9; MarylaAnd, \$136.

79. Connecticut, Indiana, Maryland, Massachusetts, New Jersey, New York, Utah, Wisconsin. 
is proportionately far below that of a used car. And, to the extent that default in automobile contracts is induced by mechanical defects, there is less probability of default by buyers of non-mechanical commodities.

On the other hand, finance charges in the automobile field seem to be no more exorbitant than those in other time-sales situations. There are also two special factors which urge extra protection to the buyer of household goods: the use of "add ons," ${ }^{80}$ and the higher degree of embarrassment and inconvenience to the buyer when the seller repossesses. ${ }^{81}$

The conclusion is inescapable that, although the automobile buyer may be slightly more in need of protection than the buyer of other consumer goods, their situations are not essentially different. Hence, the above discussion of the efficacy of statutory attempts to control abuses in automobile installment sales is largely of general applicability. The minimum requirements of any such statute should be: (1) a written contract apprising the buyer of his rights and liabilities; (2) a maximum allowable interest rate to be stated as anannual percentage in the contract so that the buyer may have some basis for comparison of costs; and (3) an option for the buyer who has a substantial equity in the goods ${ }^{82}$ to demand a resale after a repossession.

80. If the buyer purchases additional goods from the seller before completing payments under the first contract, the second contract provides for the consolidation of the purchases. Later, upon default, the seller may repossess all the goods even though the full amount of the original purchase has been paid. Some of the modern sales statutes contain provisions forbidding or limiting the use of the "add on." Forbidding: CoNNecticut, \& 6699 (a) 2; NEW JeRseY, \& $17: 16$ B-6(a) (2) ; MASSACHUSETTS, § 13B (household effects); WISCONSIN, \$122.05(2) (household effects, automobiles). Limiting: Maryland, \$124; NEw York, § 81; PA. Stat. ANN. tit. 69, $\$ 512$ (Purdon Supp. 1951) (applying only to bailment leases).

81. At least one state has felt the importance of this factor in the prior notice situation. See text at note $\mathbf{5 8}$ supra.

82. See e.g., note 68 supra. 